Meta

Journal des tradlucteurs

Translators' Journal

\title{
Sign Motivation: A Problem of Translation
}

\section{Ekundayo O. Simpson}

Volume 24, numéro 4, décembre 1979

URI : https://id.erudit.org/iderudit/004156ar

DOI : https://doi.org/10.7202/004156ar

Aller au sommaire du numéro

Éditeur(s)

Les Presses de l'Université de Montréal

ISSN

0026-0452 (imprimé)

1492-1421 (numérique)

Découvrir la revue

Citer cet article

Simpson, E. O. (1979). Sign Motivation: A Problem of Translation. Meta, 24(4),

434-441. https://doi.org/10.7202/004156ar d'utilisation que vous pouvez consulter en ligne.

https://apropos.erudit.org/fr/usagers/politique-dutilisation/ 


\section{Sign Motivation : A Problem of Translation*}

EKUNDAYO O. SIMPSON

\section{INTRODUCTION}

The problem of the motivated sign, i.e. the question of whether there is any « intrinsic and synchronously perceptible reason for the word having this particular form and no other », has not failed to attract serious linguistic attention ${ }^{1}$. The implications of the phenomenon involved for the theory and practice of translation have, however, hardly been given systematic treatment ${ }^{2}$. We shall in this paper discuss in broad outlines the relationship between sign motivation and translation. It will be shown that much of what hitherto has been intuitively recognized not only as translation difficulty but indeed as impossibility in translation can be rationally explained, viewed from the angle of sign motivation.

The notion of motivation is a relative phenomenon. Whereas the generality of the signs of every linguistic system are arbitrary or conventional, it is possible to relate the form of the motivated sign with the idea represented.

But the absence of motivation in a given sign must not be taken to mean the absence of differential associations and relationships with other signs of the same system. This is so, as Saussure has pointed out, when sign is viewed from its two constitutive elements, signifiant and signifié. Hence an arbitrary sign differs in its signifie from others of the same state of a given language in that it is determined by the various forms of associations that may be closely or remotely established with all other signifiés within the linguistic system. With regard to its signifiant, an arbitrary sign, Fr. 'arbre', for instance, is determined by all the

Paper read at the 5th International Congress of Applied Linguistics, August 1978, Montreal.

1. Stephen Ullmann, The Principles of Semantics, Oxford, Basil Blackwell, 1967, p. 86-87. Ullmann's work and Charles Bally's, Linguistique générale et linguistique française (Berne, 1965), give a fairly systematic treatment of the problem of motivation and indicate other useful literature on the subject. See also Ch. Bally, Traité de stylistique française (3rd ed., Geneva-Paris, 1951) and his «L'Arbitraire du signe», Français moderne, viii, 1940, 193-206.

2. Jean-Paul Vinay and Jean Darbelnet, Stylistique comparée du francais et de langlais : méthode de traduction, Montreal, Beauchemin (rev. version, 1970), call attention to motivation in their treatment of plan du réel and plan de l'entendement relating to English and French respectively. On the other hand, Alfred Malblanc, Stylistique comparée du français et de l'allemand : essai de représentation linguistique comparée et étude de traduction, Paris, Didier, 1968, treats the expressiveness of German terms, compared with French. 
signifiants with which it contracts formal contrastive associations : cabre, sabre, glabre, délabre ; zèbre, guèbre, ténèbre, lèpre ; lettre, litre, libre, etc.

\section{TYPOLOGY OF SIGN MOTIVATION}

In general terms, therefore, motivation can be refiected in both the signifie and the signifiant. The first type includes the category pinpointed by Saussure, in which two terms not necessarily motivated, combine to form a relatively motivated compound term, e.g. 'vingt-deux', 'poir-ier', 'vif-argent'. The second category of motivation, ignored by Saussure, shows a more or less close relationship between meaning and the acoustic composition of the word, e.g. onomatopoieae. Ullmann's three approaches to analysis of various types of motivation, based on (i) phonetic, (ii) morphological and (iii) semantic analyses, will be used to give a broad sketch of types of motivation. The approach in fact corresponds to the three basic divisions of the linguistic system ${ }^{3}$.

\section{Phonetic Motivation}

Motivation is said to be phonetic when it focuses attention on acoustic and articulatory features. Through a process of hypostatic transposition, onomatopoeiae, exclamations, interjections, etc. may become signs and such signs are then highly motivated. Sound-symbolism shows that this is the sort of motivation deliberately and intuitively at work in poetry, for instance :

Phonetic expressiveness, which is no more than a special facet of phonetic motivation, may play a twofold affective role. By the harmonious correspondence of sound and meaning, it produces a pleasant feeling of aesthetic symmetry and consonance. Simultaneously, it reinforces the emotive impact of the sense. The latter is a resource which poetry and other varieties of affective discourse are quick to exploit ${ }^{4}$.

There can be no doubt about the expressiveness of the following French signs : 'brouhaha', 'crincrin', 'cliqueter', 'cliquetis', 'croasser', 'bourrer', 'boursoufler', 'gonfler', 'empiffrer', 'happer', 'lapper', 'vadrouille', 'fripouille', 'bredouille', 'andouille', 'citrouille', 'nouille', 'malotru', 'cocu', 'lippu' ${ }^{5}$. It is obvious that these words belong to several levels of language usage and connotation (e.g.) the pejorative) - of prime interest to stylistics and the parole level of language. No less motivated are such English sensory terms of perception such as 'grating', 'squeaking', 'hiss', 'whistle', 'glint', 'gleam', 'glimmer', 'buzz', 'thud', 'screech', 'swish', etc. (cf. mots images and mots signes of Vinay and Darbelnet).

It should be noted, however, that this type of motivation may be objective or subjective. Objectively, certain letters and phonemes actually combine to produce certain effects, to suggest certain meanings (cf. assonance and alliteration in creative writing). On the other hand, perception of this type of name-sense association is often subject to individual temperament, nature, experience, culture, etc. Moreover, sound symbolism cannot systematically account for every type of

3. See Ullmann, op. cit., p. 85-90.

4. Ullmann, op. cit., p. 103 .

5. Ch. Bally, Linguistique générale et linguistique française, p. 129-130. 
phonetic and phonetic matching within a given linguistic system, cf. the various synonyms of Eng. bit (small) and big. The implications of the foregoing for interlinguistic transfer, translation, will be considered later.

\section{Morphological Motivation}

Morphological motivation derives from the relative transparency of the constituents of a given sign, even though the different parts of the latter may not in themselves be motivated. It is the only type of motivation based on signifié recognized by Saussure. For instance, 'dix-neuf' is motivated, while 'dix' and 'neuf' are not. Many compounds and derivatives belong to this class : Eng. 'blackbird', 'forget-me-not', 'leader', 'include', 'exclude', etc. The German language is notorious for this type of motivation : 'Handschuh', 'Wanduhr', 'Kindergarten', 'Kaufmann', 'hineingehen', 'abschneiden', 'austrinken', 'schlittschuhlaufen', etc. But one should also note German 'Fräulein', Fr. 'ânesse', 'lionne', etc.

\section{Semantic Motivation}

Ullmann attributes motivation of the type centred on semantic factors to the 'most peculiar trait of changes of meaning : the coexistence of old sense and new within the same synchronous system'. Motivation exists, he says, as long as the figurative - metaphorical, metonymic, pars pro toto, etc. - character of such transfers is present to the speakers' mind ${ }^{6}$. This definition of another class of motivation therefore emphasizes once more the relative character of motivation. The point to note with figurative transfer is that, unlike other cases of motivation examined above, these signs require a definite context that would show that figurative, rather than usual, sense is involved. Bally's three examples amply illustrate this :

Dans \& une flotte de cent voiles $\gg$ (synecdoque), voile $=\ll$ bateau à voiles $\gg$; c'est un syntagme implicite, car, sans cette analyse, même inconsciente, l'expression serait simplement absurde. Soit encore « La ville est en révolution » (métonymie) : ville $=$ « habitants de la ville » (on ne saurait supposer que ce sont les maisons qui s'agitent). Si enfin « Marie est une dinde», dinde signifie nécessairement «bête comme une dinde 》(métaphore) ?

A few remarks to conclude this section. We have to stress that the question of motivation must be considered only from a synchronistic perspective. Motivation is realized only when users of a given linguistic code find or feel a correlation between 'word and object', name and sense, in the contemporary stage of development of their linguistic system. The second point is that the dosage of motivated and arbitrary signs is difficult to establish. This is because, as we have shown above, subjective considerations play a role in motivation :

Many cases are clear-cut, but others depend on the intelligence, imagination, sensitivity, and even the momentary mood and attitude of the speaker; thus the expressive potentialities of words may come to the fore in emotive

6. Ullmann, op. cit., p. 89.

7. Ch. Bally, Linguistique générale et linguistique française, p. 137. 
discourse but remain unnoticed and unexploited in rational communication. This is the secret of the revitalisation of faded metaphore in literature ${ }^{8}$.

\section{APPLICATIONS TO TRANSLATION}

So far, we have discussed motivation without a deliberate attempt to pin it down too much to a particular language or group of languages. This explains why examples have been few and far-between. All the same, English, French and German signs have been used to illustrate some basic points. In applying the notion of motivation to aspects of the problem of translation, we cannot avoid to make specific comparisons between given pairs of languages. It is obvious that every act of translation is a confrontation in terms of a given pair of languages. Here, we shall have to use for illusration German and French, on the one hand, and, on the other hand, French and English, a language similar to German at several points.

It has to be pointed out too that, in the first part of this paper, we tried as much as possible to limit consideration to the sign taken mainly in isolation. Here, we shall have not only to consider the sign as an entity within a system, but also in relation to other signs of the same system. This is because message, Vinay and Darbelnet's sens global, is the corner-stone of translation effort. In other words, the interaction of different signs in a given situation must ultimately take precedence over the value of individual signs :

Cette interaction est précisément le domaine par excellence du traducteur et elle s'opère non seulement sur le plan vertical, à l'intérieur du signe, pourraiton dire, mais également de signe à signe, sur le plan horizontal, dans le déroulement du message, de telle sorte que la totalité du message est plus grande que la simple somme des signes qui la composent ${ }^{2}$.

In brief, without failing to bring into relief the motivated or arbitrary sign, more prominence will have to be given to parole than we did in the first section, where langue was stressed.

There is a smaller number of motivated signs in French than in German. Bally explains this by the fact that German has a predilection for complex signs and compounds. Prefixes and suffixes are abundantly used by the language. French signs, on the other hand, are simple on the whole and tend to aid the memory less ${ }^{10}$. French is in fact characterized by the practice of what Saussure had called l'arbitraire du signe. There is, consequently, greater implicit motivation in French than in German, cf. Fr. 'jument', seen by the French as 'femelle du cheval', 'puer' as 'sentir mauvais', 'borgne' as 'aveugle d'un æil', etc. Although German has comparable examples of this type of motivation, e.g. 'Schimmel : white horse' (cf. Eng. 'starve : die of hunger'), there is less necessity for it, since the language readily aligns several notions in a given 'word'.

Whereas the French language shows less phonetic motivation, German makes full use of it. French does not demarcate sub-units of words as does

8. Ullmann, op. cit., p. 90.

9. Vinay and Darbelnet, op. cit., p. 29.

10. Ch. Bally, Linguistique générale et linguistique française, passim. 
German which is aided by its greater use of the accent. The uniformity of the French accent, on the other hand, confirms the language's tendency for the simple and arbitrary sign. In the same vein, the German syllable motivates, while the French one is, once again, arbitrary. In expressive language, sensory, imagebound elements play a greater role in German than in French. In fact, many phonemes and words standing apart remain highly expressive in German. These are but some of the points noted by Bally in his extensive study of the expressive resources of both German and French.

The absence of motivation at various levels in French leads to the conclusion that the simple sign is not significantly hampered by combinations likely to restrict its usage. In other words, explicit motivation, of the type frequent in German, limits the applications of the motivated German sign within the language as a whole. Hence the word 'Wanduhr', because of its transparent meaning, deriving from its two components, 'Wand' and 'Uhr', would only designate 'wall-clock', 'hanging clock'. And with this, we are already in the sphere of translation.

If the motivated sign is limited in its application by its highly charged semantic nature, it follows that it would, barring a coincidence, resist close translation into a language which tends to motivate less, in which the equivalent to be found would be a simple word, in the sense of arbitrary as used by Bally. Perhaps in technical texts, and general texts, the pitfalls to be met in going from the motivated, complex sign to the arbitrary, simple sign, will not be very apparent. However, in texts where expressive, affective or emotive elements are supposed to be a function of meaning, translation risks being inadequate, since key terms would be 'simplified'.

It is obvious, then, that there would be more losses in poetic translation when one moves from German to French ${ }^{11}$. It is the case that the greater the creative character of a source text, the less adequately German would be translatable into French. But, conversely, the more scientific the source text, the more adequately the French language would render the German.

Because of the arbitrary nature of a large number of its signs, at least when compared to languages like English and German, the French language has to search for the precise term at every point, and context turns out to be of paramount importance. This is so even when the problem is on the level of intralinguistic communication :

le sens n'étant fixé que par associations, il est naturel que ces associations tendent à se réaliser dans la parole. Cela découle ensuite de la multiplicité des sens dont se charge le signe arbitraire dans une langue qui motive peu. Chacun de ces sens ne peut être convenablement fixé que par l'appoint d'un contexte ou d'une situation. C'est le cas en français, et dès lors, le souci de la propriété des termes, qui hante l'esprit de toute personne désireuse de bien parler sa langue, apparaît sous un jour nouveau ${ }^{12}$.

11. See Meta, numéro spécial, 23, 1 (mars 1978), La traduction poétique.

12. Ch. Bally, Linguistique générale et linguistique française, p. 343. 
This characteristic of the French language consequently assumes greater significance in interlinguistic communication.

We should not assume, however, that a language like French, with its simple signs, cannot resort to motivations that would create problems of translation into more motivated languages such as German and English. The contrary is the case. Because of a high incidence of simple words with multiple meaning (polysemy), on the one hand, and also what we shall call the coincidence whereby very many groups of different words share the same sounds (homonymy), the possibility of puns and word-plays is very high in every language. Added to the problems created by homonymy and polysemy, however, are the characteristic elision, liaison and the uniform open syllabification of the French language. The point that interests translation here may be obvious but has to be stressed. In the first place, as long as one has to move from one language to the other, there has to be automatic loss, from the point of view of sign motivation : every sign used in translation creates its own series of 'associative fields' through motivation internal, i.e. implicit, and external, explicit (phonetic, morphological and semantic). Secondly, where source language explicit motivation is due to such semantic elements as polysemy, homonymy, shifts in application, emotive or affective elements (cf. loan expressions, dialectal, social, technical vocabulary), such elements may not be carried over adequately along with message into the target language. The fact, for instance, that each of the following two statements, with completely different meanings, can recall the other in the receiver's mind has been pointed out by Bally : 'c'est là qu'on fait des rations' and 'c'est la confédération'. This relationship will obviously be lost in translation. It is the case, consequently, that puns and word-plays, etc., lose their essence in translation. Here, the translator would have to create other appropriate puns deriving from his own language.

I shall conclude by quoting two translations of poetry that show what types of losses and gains can occur in translation, owing to sign motivation, or the lack of it, even where good translators are involved. Jules Supervielle's 'Chanson' as translated by Paul Celan illustrates what George Steiner calls 'transfiguration', i.e. where the target language improves on a source text. Supervielle's text is a simple one, full of stock phrases :

Jésus, tu sais chaque feuille

Qui verdira la forêt,

Les racines qui recueillent

Et dévorent leur secret,

La terreur de l'éphémère

A l'approche de la nuit,

Et le soupir de la Terre

Dans le silence infini.

Tu peux suivre les poissons

Tourmentant les profondeurs,

Quand ils tournent et retournent

Et si s'arrête leur ccour... ${ }^{18}$ 13. Quoted by George Steiner, After Babel : Aspects of Language and Translation, London,
Oxford University Press, 1975, p. 404. 
Paul Celan's translation exploits the expressiveness of the German language, more motivated than French :
Jesus, du kennst sie alle :
das Blatt, das Waldgrün bringt,
die Wurzel, die ihr Tiefstes
aufsammelt und vertrinkt...
die Angst des Taggeschopfes,
wenn es sich nachthin neight,
das Seufzen dieser Erde
im Raum, der sie umschweigt.
Du kannst den Fisch begleiten,
dich wuhlen abgrundwarts
und mit ihm schwimmen, unten, und langer als sein Herz... ${ }^{14}$

The obvious gain in expressiveness is achieved through the use at several points of such concrete terms or compounds as 'Waldgrün' (forêt), 'Wurzel' (racines), 'Tiefstes' (secret), 'aufsammelt und vertrinkt' in the place of Supervielle's recueillent et dévorent, 'Taggeschopfes' for éphémère, etc. And even where the original author uses a term, terreur, for which German has a borrowed equivalent, Terror, Celan chooses that most poetic, and pathetic of German literary terms, Angst.

The other text moves from English to French. And it proves that English is close to German in terms of motivation and expressive resources. We recall that the Irish writer, Samuel Beckett, had preferred to compose many of his works, plays, novels, etc. in French (and then translate into English at a later date), because he could not, as he put it, stop writing poetry in English. French, in other words, calls for simpler and more precise terms. Pierre Leyris' translations from Gerard Manley Hopkins not only show the comparative resources of English and French, they highlight to a great extent the problem of sign motivation when the consideration is interlinguistic. 'Pied Beauty' is, according to Steiner an 'impossibility' if ever there was in translation :

Glory be to God for dappled things -

Gloire à Dieu pour les choses bariolées,

For skies of couple-colour as a brinded cow ;

Pour les cieux de tons jumelés comme les vaches tavelées,

For rose-moles all in stipple upon trout that swim ;

Pour les roses grains de beauté mouchetant la truite qui nage;

Fresh-firecoal chestnut-falls ; finches' wings ;

Les ailes des pinsons; les frais charbons ardents des marrons chus; les paysages

Landscapes plotted and pieced - fold, fallow, and plough ;

Morcelés, marquetés - friches, labours, pacages;

And all trades, their gear and tackle and trim.

Et les métiers: leur attirail, leur appareil, leur fourniment.

All things counter, original, spare, strange ;

Toute chose insolite, hybride, rare, étrange,

Whatever is fickle, freckled (who knows how ?)

Ou moirée, madrurée (mais qui dira comment?)

14. Quoted by G. Steiner, op. cit., p. 404-405. 
With swift, slow ; sweet, sour ; adazzle, dim;

De lent-rapide, d'ombreux-clair, de doux-amer,

He fathers-forth whose beauty is past change :

Tout jaillit de Celui dont la beauté ne change :

Praise him.

Louange au Père ${ }^{15}$,

I hope that I have been able to indicate in this short essay one area of translation difficulty and limitation, if not impossibility, along the lines called for by Georges Mounin ${ }^{16}$.

15. Quoted by G. Steiner, op. cit., p. 412-413.

16. \&La traduction n'est pas toujours possible : elle ne l'est que dans une certaine mesure, et dans certaines limites - mais au lieu de poser cette mesure comme éternelle et absolue, il faut dans chaque cas déterminer cette mesure, décrire exactement ces limites; il faut faire la statistique des échecs traductionnels », George Mounin, Problèmes théoriques de la traduction, Paris, Gallimard, 1963, p. 273-274, 